\title{
Production and Evaluation of Some Specialty Products Prepared from Shoot Tip (Gommar) of Zagloul Date Palm Tree ( Phoenix Dactylifera)
}

\author{
Magda,S.Sharara; E.S.M.Abou-Tour \& A.A.Abdel-El-Nabey 1
}

\begin{abstract}
Shoot tip (Gommar, GOM) of Zagloul date palm tree (Phoenix dactylifera) and its dehydrated flour ( DGF) were analyzed and characterized in terms of physico-chemical, microbiological and technological utilization in preparation of popular products such as fresh cut strips, frozen cubes, jam as well as fruit salads. Incorporation of DGF in biscuits, cookies, belellah and rice pudding were also studied. The result showed that GOM had a value of 8.0 Brix $^{0}$ for total soluble solids and a pH value of 6.23 . Titratable acidity as \% citric acid was $0.299 \%$. No detectable levels of total viable count and coliform group were found in both fresh GOM and its dehydrated flour (DGF) . Reducing sugar represented about $84 \%$ of the total sugars. Fresh GOM and DGF could be considered as a good source of minerals especially $\mathrm{K}$, Na and $\mathrm{Ca}$. Relatively significant amount of dietary fiber and inulin were present in fresh GOM and DGF and thus could be considered as promising and cheap source of these compounds and can be used as a natural antioxidant in spite of its lower content of vitamin $\mathrm{C}$ and phenolic substances. The presence of high amount of $C_{18: 2} \quad n_{6}$ and $C$ 18:3 $n_{3}$ suggests that GOM oil is a highly nutritious . The shelf life of fresh cut GOM under refrigeration storage at $10{ }^{\circ} \mathrm{C}$ was about 12 days. The different products prepared from fresh cut GOM or its dehydrated flour (DGF) were highly acceptable by panelists.
\end{abstract}

Key words: Shoot tip (Gommar), heart of palm date, chemical composition, technological utilization.

\section{INTRODUCTION}

Date palm trees are attacked by the red palm mute Coleoptera curculionidae. This field pest is abundant in many parts (zones) in Egypt and cause big economic damages (Farag, 2004). This insect is capable of attacking the palm tree at its top (Gommar) or as it called shoot tip. The most important recommendations for the control of this pest is to burn the infested trees (Abdalla et al ., 2008). To avoid the attack of this pest, many farmers are advised to cut the palm trees and make use of the shoot tip or Gommar by selling it to the public after cutting it into small pieces, usually under non hygienic way which may cause different diseases to the consumer.

Heart of palm, also called palm heart, palmito, burglar' s thigh, chonta, palm cabbage is harvested from the inner core and growing bud of certain palm trees in Ecuador, Costa Rica and Brazil. When harvesting the cultivated young palm, the tree is cut down and the bark is removed leaving layers of fibers around the center core. The center core is attached to a slightly more fibrous cylindrical base with a larger diameter. The entire cylindrical core and the attached base are edible and called millionaire's salad (Sylvester and Avalos, 2009). Hearts of palm have no cholesterol, have excellent fiber content, hardly any fat content, and are low in calories. Hearts of palm may be packaged fresh, or jarred in water, and may be served raw or cooked. It can be sliced and add to salads, grains, pastas and fresh salsas. Thin slices can be used as top pizza, stuff or fill hollow cavity with cheeses, meats or herbs. Also it can be added to stews, chowders, quiche and casseroles. Due to its mild flavour, hearts of palm date pair well with greens and seafood.

Information is scarce regarding the chemical and technological characteristics of the edible portion of the common shoot tip of Zagloul date palm trees (Gommar) cultivated in Egypt. Therefore, the present work aimed to determine the chemical composition as well as some technological processes to utilize this edible part in some food products.

\section{MATERIALS AND METHODS}

\section{Materials:-}

Whole shoot tip of Zagloul palm date tree (Gommar, GOM) was obtained from a private farm located at Idkou, Behiera Governorate, Egypt, at the beginning of April 2011. This GOM was weighted about $20 \mathrm{~kg}$ and was freed from mechanical damages and defects. The general appearance of GOM is shown in Fig.(1). GOM sample was brought to the pilot plant of Food Science and Technology Department, Faculty of Agriculture, Alexandria University, Egypt. GOM sample was divided into small pieces. These pieces were subdivided into cubes $(1 \times 1 \times 1 \mathrm{~cm})$ or strips of approximately $5 \mathrm{~cm}$ length, $1.5 \mathrm{~cm}$ width and $2 \mathrm{~mm}$ thickness. The strips were placed in polypropylene shallow trays, then tightly wrapped with cling paper and placed in a refrigerator at $10{ }^{\circ} \mathrm{C}$ and $70 \% \mathrm{RH}$, and stored for 1 month. Part of the cubes was soaked in citric acid solution $(0.4 \%)$ for 5 min, then blanched in boiling water at $100^{\circ} \mathrm{C}$ for $10 \mathrm{~min}$, followed by rapid cooling and then freezing. The aforementioned frozen sample was stored for 3 months at $-18{ }^{0} \mathrm{C}$. Part of the blanched cubes was used for

${ }^{1}$ Dept. of Foof Science \&Technology, Fac. of Agric.,

Alex. University, Alex,Egypt

Received June15, 2012, Accepted June29, 2012 
producing fruit salads and jam. Part of the fresh cubes was minced, packed in glass kilner jar and stored at $-18{ }^{0} \mathrm{C}$ until used. Another part of the blanched cubes was minced then loaded on drying trays in a thin layer, dehydrated by hot air at $55{ }^{0} \mathrm{C}$ for $24 \mathrm{hr}$ in a thermostatically controlled oven with air fan (Von loesecke, 1955). The dehydrated cubes (flakes) were ground electrically in a mill ( wiley, model 4, England) to pass through 80 mesh sieve to obtain dehydrated Gommar flour (DGF). The obtained flour was packed in air- tight kilner jar and stored in a refrigerator at $4{ }^{0} \mathrm{C}$ until used. All the other ingredients used in the present study were obtained from Alexandria markets, Egypt.

\section{Methods:-}

Weight loss of fresh cut GOM during refrigeration:The weight of freshly harvested strips of GOM was monitored and recorded intervals up to about one month.

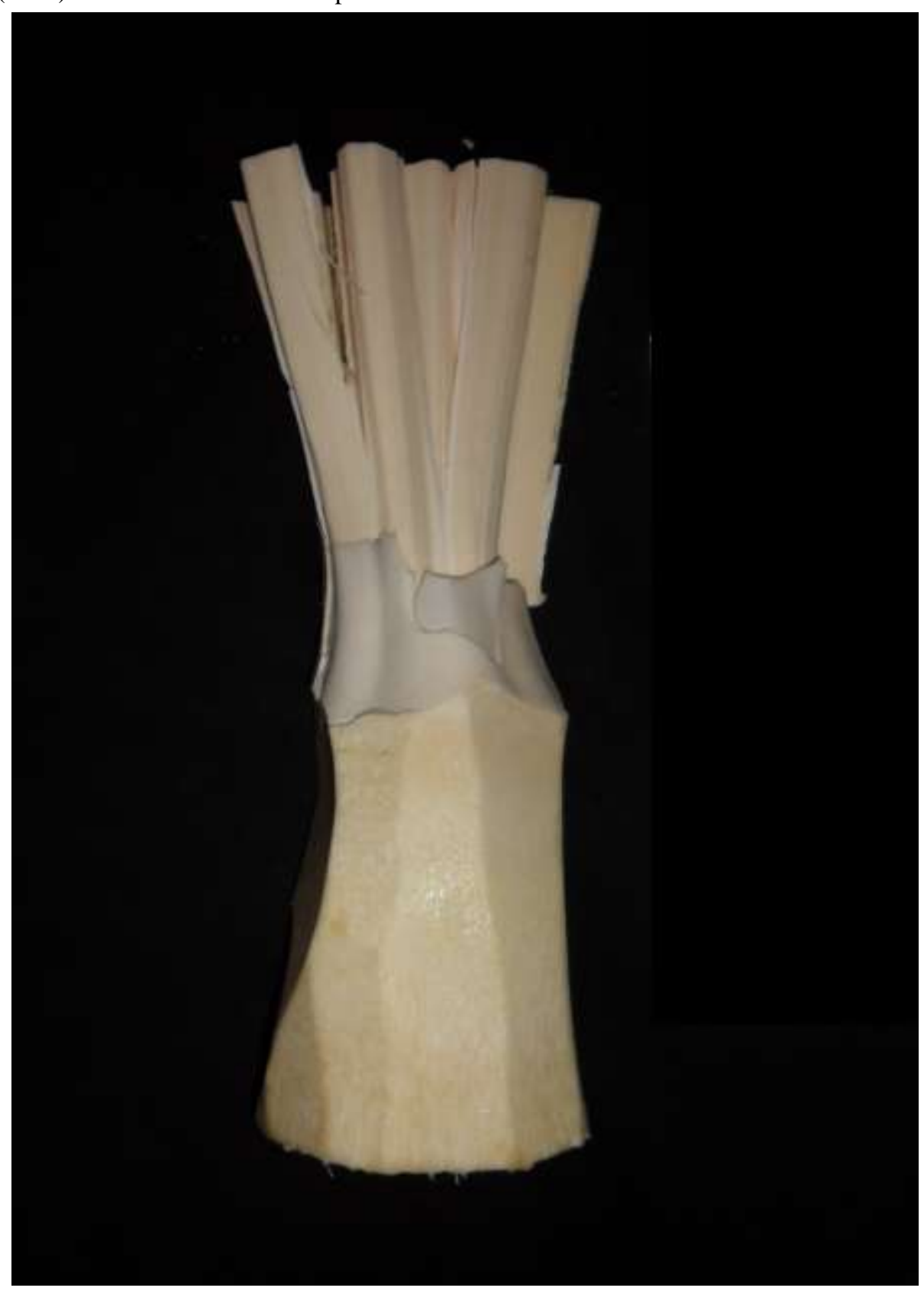

Fig . 1. The general appearance of GOM 


\section{Chemical methods:-}

Enzyme activities:-Enzyme activities of catalase and polyphenoloxidase in fresh and blanched cubes of GOM were tested according to Galeazi et al. (1981), while peroxidase activity was tested according to the procedure of Olmos et al. (1997).

Total soluble solids (TSS), pH and titratable acidity:Total soluble solids of fresh GOM and the liquor syrup of fruit salads containing GOM cubes were measured by using hand refractometer $\mathrm{N}_{1}$ (Brix 0-32\%), Atago Co., Ltd, Japan. On the other hand pH of fresh GOM as well as the liquor syrip of fruit salads was measured by using CD 620 pH meter, Gallenkamp, UK. Titratable acidity expressed as percentage of citric acid of liquor syrup of fruit salads containing GOM cubes was determined by titrating 5-9 gm samples with $0.01 \mathrm{~N} \mathrm{Na} \mathrm{OH}$ to $\mathrm{pH} 8.1$ according to Ranganna, (1977).

Proximate analysis:-Proximate analysis of GOM of Zagloul date palm including moisture, crude protein $(\mathrm{N}$ $x$ 6.25), crude ether extract, total ash and crude fiber were carried out according to the AOAC (1998) procedures. Carbohydrates were calculated by difference. Total sugars (reducing and non reducing) were determined using Lane and Enon procedure as stated in AOAC (1998).

Minerals: - ( $\mathrm{Fe}, \mathrm{Cu}, \mathrm{Mg}, \mathrm{Ca}, \mathrm{Mn}, \mathrm{Zn}, \mathrm{Cd}$ and $\mathrm{Pd})$ were measured as described in the AOAC (1998) using Perkin Elmer Atomic Absorption Spectrophotometer (Model 2380). On the other hand, $\mathrm{Na}$ and $\mathrm{K}$ were determined using flame photometer Model PEP7.

Ascorbic acid determination- Ascorbic acid was determined according to AOAC (1998) procedure using 2,6 dicholorophenol, indophenol dye.

Phenolic compound determination:- Phenolic compounds as $\%$ tannic acid were determined by FolinCiocaltu reagent as descrided by Ranganna (1977) after extraction with $70 \%$ ethanol according to Naczk and Shahidi (1989).

Inulin determination:- Inulin was extracted by hot deionized water according to the method of Van Waes et al. (1998). The colourometric dinitrosalicylic acid (DNSA) method (Plummer, 1978) was used for determining the hydrolyzed inulin as fructose.

Dietary fiber content:- Total dietary fiber (TPF) content was determined according to the enzymaticgravimetric method described by Prosky et al. (1985) .

Antioxidant activity:- Antioxidant activity was measured by the N,N- Dimethyl- p- phenylenediamine dihydrochloride (DMPD) according to Fogliano et al. (1999).
Fatty acids composition and oil classes:- Total lipids were extracted with chloroform: methanol $(2: 1, \mathrm{v} / \mathrm{v})$ as outlined by the procedure of Folch et al.(1957) . Total lipid extract was fractionated into different classes using a TLC technique according to the method of Mangold and Malins (1960) on glass plates $(20 \times 20 \mathrm{~cm})$ precoated with $0.25 \mathrm{~mm}$ silica gel. G-60. The developing solvent system used was petroleum ether: diethyl ether: glacial acetic acid (70:30:2). After running, the plate was air dried and the separated spots were visualized by iodine vapour. Lipid classes were identified by their Rf values according to Rahma and Abd El-Aal (1988).

Fat sample was extracted using petroleum ether and diethyl ether, and then the methyl ester was prepared using methanol- $\mathrm{H}_{2} \mathrm{SO}_{4}$ acid. Gas chromatographic analysis was carried out using ACME model 6100 GC (Young LIN Instrument Co., Korea) fitted with a split/split less injector and FID detector, Nitrogen was used as the carrier gas with a flow rate of $0.5 \mathrm{ml} / \mathrm{min}$. The components were separated on a $30-\mathrm{m}$ SP-2380 fused-silica capillary column with a $0.25-\mathrm{mm}$ i.d. and $0.2-\mu \mathrm{m}$ film thickness (Supelco, Bellefonte, PA), the detector temperature was set at $260{ }^{\circ} \mathrm{C}$. The injector temperature was set at $220^{\circ} \mathrm{C}$ and in split mode (split ratio 80:1). The column was initially maintained at $140{ }^{\circ} \mathrm{C}$ for $5 \mathrm{~min}$, and the temperature was subsequently increased to $240^{\circ} \mathrm{C}$ at a rate of $4{ }^{\circ} \mathrm{C} / \mathrm{min}$, (total program time $30 \mathrm{~min}$ ).

Microbiological examination:- Total plate count and coliform group were determined in fresh GOM and DGF according to Gerhardt et al. (1994).

Microscopic examination:- Microscopic examination of GOM strips stored at refrigerator was assessed according to the following procedure:-

A cube of GOM $(1 \times 1 \times 1 \mathrm{~cm})$ was washed with sterilized water, surface sterilized by soaking in $1.0 \%$ $\mathrm{NaOH}$ for 1.0 min. rinsed several times with sterilized water then divided into small pieces $(0.5 \times 0.5 \times 0.5$ $\mathrm{cm}$ ), flamed and finally cultured in $10 \mathrm{~cm}$ diam. petri dishes contained potato dextrose agar (PDA) medium and incubated at room temperature $\left(27 \pm 3{ }^{0} \mathrm{C}\right)$. The resultant hyphal growths were purified by subculturing an active margin of fungal colony using sterilized needles in the same media. The purified hyphal growth were subculured also in test tube contained slant PDA media and incubated at room temperature for 7 days then kept at $5^{\circ} \mathrm{C}$. The hyphal growths were examined using light microscope and identification of the fungi was done using the key described by (George and Agrios, 1978). 
Technological methods:-

GOM Jam and fruit salads: - Fig. (2) shows the flow sheet used for producing GOM jam (control, GOM + rose flavouring agent and GOM + banana flavouring agent) and fruit salads containing GOM cubes alone (control) or with another fruit cubes such as loquat, strawberry, peach, nectarine, husk tomato or a mix of the above fruits $(3: 1 \mathrm{w} / \mathrm{w})$.

Biscuits:- Biscuits(aniseed and ammonium) were processed according to the method described by Askar (1991). Effect of supplementing 2.5, 5.0 and 7.5\% DGF of weight flour on the biscuits' quality was studied. The biscuits formula is as follows:-

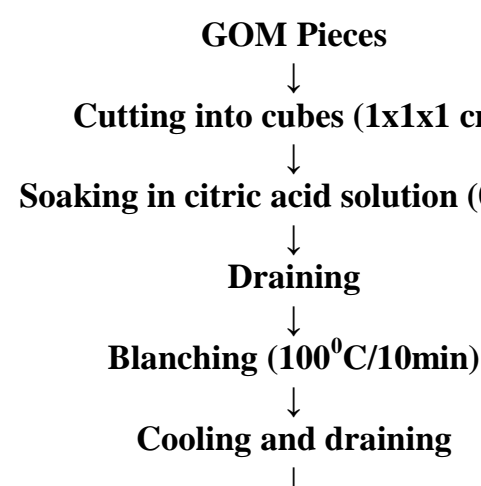

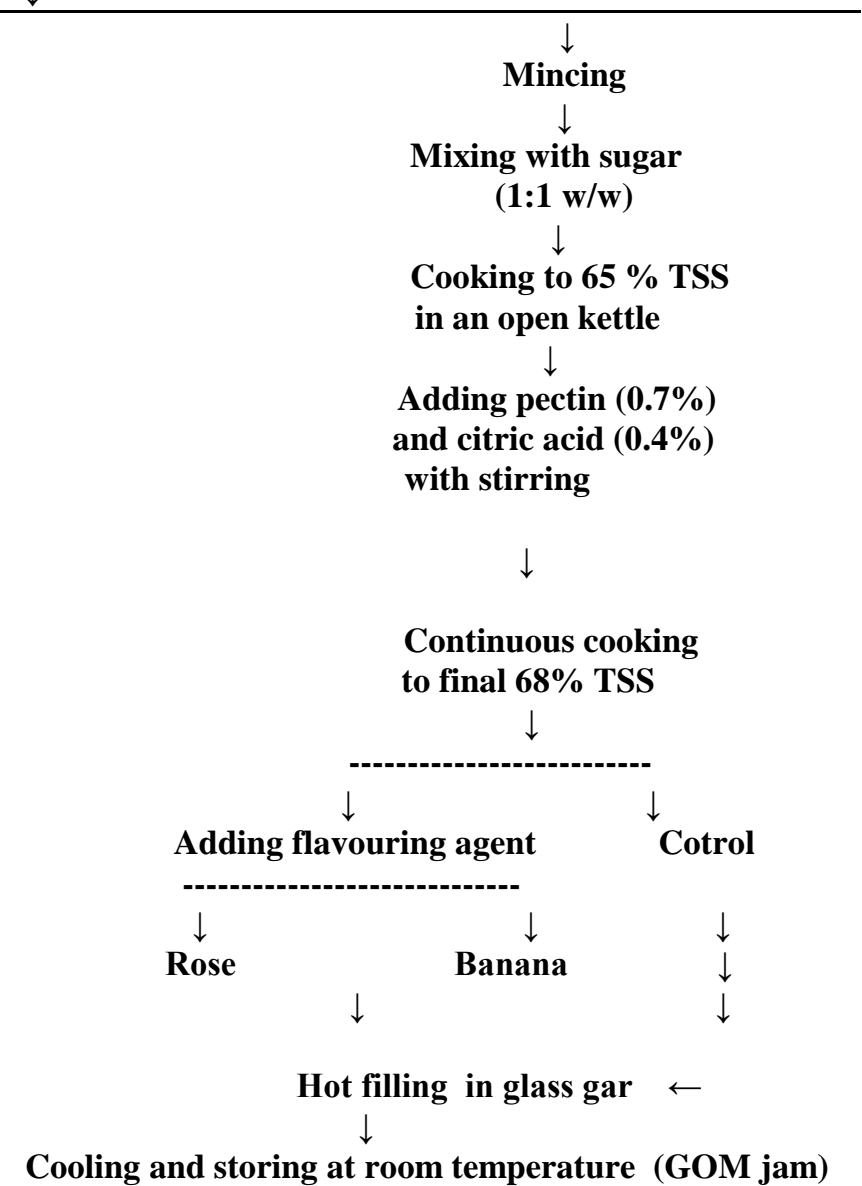

Fig. 2. Flow sheet for processing GOM jam and fruit salads containing GOM 


$\begin{array}{lcc}\text { Ingredient } & \begin{array}{c}\text { Aniseedbiscuit } \\ (\mathrm{gm})\end{array} & \begin{array}{c}\text { Ammonium biscuit } \\ (\mathrm{gm})\end{array} \\ \text { All purpose flour } & 250 & 250 \\ \text { (72\% extraction) } & & \\ \text { Sunflower oil } & 75 & ---- \\ \text { Sodium bicarbonate } & 0.50 & 0.50 \\ \text { Shortening } & --- & 100 \\ \text { Ammonium bicarbonate } & --- & 1.25 \\ \text { Powdred sugar } & 100 & 100 \\ \text { Sodium chloride } & 1.00 & 1.00 \\ \text { Egg } & 2(\text { whole }) & 1(\text { whole }) \\ \text { Baking powder } & 8.00 & 4.00 \\ \text { Vanilla } & 5.00 & 2.00 \\ \text { Water or milk } & --- & 25 \mathrm{ml}\end{array}$

All ingredients were mixed in the Hobart dough mixer (Model N-50G, $470 \mathrm{rpm} . \mathrm{H}_{\mathrm{z}} 50$ ) for 7 min at 470 $\mathrm{rpm}$. The dough was flattened using sheeting roll machine and shaped. Baking was performed at $150{ }^{\circ} \mathrm{C}$ for $15 \mathrm{~min}$. Biscuits were allowed to cool and stored in polyethylene bags at ambient temperature.

Chocolate chip cookies:- Chocolate chip cookies were prepared from the following ingredients $(250 \mathrm{gm}$ allpurpose flour, $125 \mathrm{gm}$ shortening, $125 \mathrm{gm}$ brown sugar, $62.5 \mathrm{gm}$ granulated sugar, $2.5 \mathrm{gm}$ vanilla, 1 egg beaten, $2.5 \mathrm{~g}$ baking soda, $1 \mathrm{gm}$ salt and $125 \mathrm{gm}$ chocolate chips. Effect of supplementing 2.5, 5.0 and 7.5\% DGF of weight flour on the cookies quality was studied. Shortening and sugars were creamed, and then beaten eggs and vanilla were added. Flour, baking soda, salt, chocolate chips and DGF were combined all together and added to the creamed mixture. The mixture was dropped by teaspoonful onto a cookie sheet leaving 5 $\mathrm{cm}$ between cookies. Cookies were baked at $180{ }^{\circ} \mathrm{C}$ for 10-12 min until golden. Cookies were removed from sheet and leave to cool before packaging in polyethylene bags and kept at ambient temperature.

Belellah:- Belellah was prepared from clean, washed and steeped wheat grains in addition to DGF at levels of 2.5, 5.0 and $7.5 \%$ of wheat grain weight. Steeping in water was carried out by soaking the dry clean and washed wheat grains in water (1:4 by weight) at room temperature for $10 \mathrm{hrs}$. The grains and DGF were boiled in water in a proportion of approximately $(1: 8 \mathrm{w} / \mathrm{v})$. Boiling was continued 1 to $1.5 \mathrm{hrs}$ to a condition of proper cooking. Warm belellah samples were sweetened with little amount of sugar (15 gm /100 gm of wheat) and enough amount of milk, before subjecting to organoleptic evaluation ( Abd- Elsalam, 2011).
Rice with milk product (rice pudding):- This product was prepared according to the recipe and the tradition method applied at home using the following ingredients:-250 gm fresh milk. 125 gm milled rice, 125 gm sugar. $25 \mathrm{gm}$ corn starch and small amount of vanilla. Effect of supplementing 2.5, 5.0 and $7.5 \%$ DGF of weight milled rice on the quality of the final product was studied.

Sensory evaluation of GOM products:- Colour, taste, odour, texture and overall acceptability of GOM products including jam, fruit salads and its liquor, biscuits, chocolate chip cookies, belellah, rice pudding as well as the frozen cubes of GOM during the storage period (3 months) were assessed using 15 panelists of Food Science and Technology Department, Faculty of Agriculture, Alexandria University. The panelists were asked to score the above attributes according to a standard hedonic rating scale from 9 (like extremely) to 1 (dislike extremely) according to Kramer and Twigg, (1970).

Statistical analysis:-Data of chemical composition and organoleptic properties were subjected to analysis of variance using Duncan's multiple range test with SAS system (Steel and Torrie, 1980). Histograms were produced using Harvard graphics software (HG, version, 5. 2003).

\section{RESULTS AND DISCUSSION}

\section{Physico- chemical and microbiological properties of fresh GOM:-}

As shown in Table (1), the total soluble solids (TSS) of GOM were $8 \%$. However, the TSS value of GOM were lower compared with those reported for other fruits such as raspberry $(13.9 \%)$, apple (14.0\%), blackberry $(15.4 \%)$, black cherry $(18.7 \%)$ black currant $(19.7 \%)$ and husk tomato (13\%) (Abo-Gharbia and Abou-Tour, 2001, Kirk and Sawyer, 1991). As shown from Table (1), GOM followed the non-acidic foods with a $\mathrm{pH}$ of 6.23 . For this reason, acidification is necessary before manufacturing GOM into different products such as jam and fruit salads. In accordance, titratable acidity expressed as \% citric acid of GOM was very low $(0.299 \%)$. The data in Table (1) also show that catalase, peroxidase and polyphenoloxidase in the fresh GOM were very active, thus it is very important to inactivate these enzymes before processing. From the microbiological point of view, it has been found that the fresh GOM and its dehydrated flour contained non detectable levels of total viable count and coliform group. This indicates that good and sanitizing practices were applied during obtaining and transporting or handling the fresh GOM. 
Table 1. Physico-chemical properties of fresh GOM

\begin{tabular}{ll}
\hline Property & Value $^{*}$ \\
\hline TSS & $8.0 \pm 0.14$ \\
(Brix) & \\
pH & $6.23 \pm 0.12$ \\
Titratable & $0.299 \pm 0.02$ \\
Acidity & \\
(as \%citric acid) & \\
Catalase & +++ \\
Peroxidase & +++ \\
Polyphenoloxidase & +++ \\
Total viable count & $\mathrm{ND}^{* *}$ \\
Coliform group & $\mathrm{ND}^{* *}$ \\
\hline
\end{tabular}

${ }^{*}$ Mean \pm SD

$+++=$ Very active

${ }^{* *}$ Not detected

\section{Chemical composition of fresh GOM and DGF:-}

The data shown in table (2) indicate that moisture was the major component of fresh GOM. Therefore it was subjected to rapid deterioration if it was kept at room temperature. The storage of fresh GOM in refrigerator at $4{ }^{0} \mathrm{C}$ is necessary to extend its shelf life. Total carbohydrates represented $61.99 \%$ of the total solids content of the fresh GOM (on dry weight basis). It was followed by crude protein, total ash and crude ether extract. Table (2) also shows that fresh GOM had 7.34\% total sugars in which $83.92 \%$ were reducing sugars. The data of Table (2) show that fresh GOM had considerable amount of total dietary fibers being $465.42 \mathrm{mg} / 100 \mathrm{gm}$ (on dry weight basis). Dietary fibers decrease the risk of diverticular disease, play an essential role in the physiology of the gastrointestinal tract and modify the absorption of nutrients in the small bowel. Moreover, dietary fibers accelerate the gut transit time, affect stool composition and quantity, encourage the growth of colonic microflora, release the detoxicating enzymes, antioxidants and carcinogen inactivating compounds (Trepel, 2004) . Fresh GOM was poor in ascorbic acid or vitamin $\mathrm{C}$ compared with other fruits which were fair in their content of vitamin C. Data in Table (2) indicate that the concentration of phenolic substances as tannic acid in fresh GOM were $314.91 \mathrm{mg} / 100 \mathrm{gm}$ (on dry weight basis). The low level of phenolic substances in fresh GOM makes it already palatable. The results presented in Table (2) show that inulin was found in fresh GOM at significant amount $(22.44 \%$ on dry weight basis). The relatively significant amount of inulin present in fresh GOM leads to considering it as a promising and cheap source of inulin. Inulin is positively influencing the composition of the gut microflora, and there are indications of beneficial effects on mineral absorption, blood lipid composition, and prevention of colon cancer. (Pool-Zobel, 2005). In addition, inulin is a low calorie fiber that has potential rule for its use in the production of fat- reduced foods (Gupta et al., 1993, Hellwege et al., 2000 \& Lamers et al., 2003). Antioxidant activity of fresh GOM was recorded to be $49.00 \%$.The value indicated that fresh GOM can be used as a natural anioxidant (Takeoka et al., 2001, Gil et al., 2002, Wada and Ou, 2002 \& Jiratanan and Liu, 2004). The chemical composition of DGF is also illustrated in Table (2). It can be concluded that DGF is a good source of total dietary fiber, inulin and antioxidant activity, in addition to its high content of crude protein, ash and crude ether extract. Accordingly, this flour can be utilized in certain food products popular in Egypt.

\section{Mineral content of fresh GOM and DGF:-}

As seen in Table (3), ash of fresh GOM and DGF consisted of macro and micro elements. These elements could be arranged according to their concentration (ppm on dry weight basis) in the following decreasing order: $\mathrm{K}, \mathrm{Na}, \mathrm{Ca}, \mathrm{Fe}, \mathrm{Mn}, \mathrm{Cu}, \mathrm{Pd}, \mathrm{Mn}$ and $\mathrm{Zn}$. This is an indication that fresh GOM and DGF could be considered as a good source of minerals especially $\mathrm{K}$, $\mathrm{Na}$ and $\mathrm{Ca}$.

Fatty acid composition and lipid classes of fresh GOM:-

Table (4) shows the fatty acid composition of the total lipids of fresh GOM. The fatty acid pattern revealed that the saturated fatty acid content of fresh GOM was $36.19 \%$ whereas the unsaturated fatty acid content was $63.03 \%$. Linoleic acid $\left(\mathrm{C}_{18: 2} \mathrm{n}_{6}\right)$ was found to be the dominant fatty acid, being $39.20 \%$ followed by palmitic acidC $\mathrm{C}_{16: 0}$ being $29.96 \%$, and oleic acid $\left(\mathrm{C}_{18: 1}\right.$ $\mathrm{n}_{9}$ ). Small amounts of myristic, stearic and arachidic acids were also present. It can be noted from the data in 
table (3) that GOM oil contains a considerable level of $\mathrm{C}_{18: 3} \mathrm{n}_{3}$ which has been known to be one of the $\mathrm{w}_{3}$ fatty acids. The presence of high amount of the essential fatty acids $C_{18: 2} n_{6}$ and the $w_{3}$ fatty acid $\left(C_{18: 3} n_{3}\right)$ suggests that this oil is a highly nutritious due to the ability of unsaturated oils to reduce serum cholesterol. The ratio of unsaturated to saturated fatty acids was $1.74: 1$ which is quite close to that of the common edible vegetable oils in which their degree of unsaturation were quite high.
The results of the fractionation of the total lipid classes of GOM are shown in Fig (3). The results indicated that total lipids of fresh GOM consisted mainly of 8 fractions of glycerides and non-glyceride compounds in addition to the polar lipid class located on the base line. Triacylglycerols were found to be the major fraction of GOM lipids. On the other hand, the other classes can be arranged based on their RF as follows: monoacylglycerols. 1,2 and 2,3 diacylglycerols, sterols, 1, 3 diacylglycerols, unknown, free fatty acids and hydrocarbons and sterol esters based on the front line.

Table 2.Chemical composition of fresh GOM and DGF

\begin{tabular}{|c|c|c|c|c|}
\hline \multirow[t]{2}{*}{ Component } & \multicolumn{2}{|c|}{$\begin{array}{c}\text { *Value } \\
\text { Fresh GOM }\end{array}$} & \multicolumn{2}{|c|}{ DGF } \\
\hline & (A) & (B) & (A) & (B) \\
\hline Moisture (\%) & $84.44 \pm 1.95$ & ---- & $4.039 \pm 0.64$ & ----- \\
\hline Crude protein $(\%)$ & $3.61 \pm 0.26$ & $23.20 \pm 0.51$ & $20.461 \pm 0.37$ & $21.322 \pm 0.44$ \\
\hline Crude ether extract $(\%)$ & $1.05 \pm 0.37$ & $6.76 \pm 0.82$ & $5.613 \pm 0.47$ & $5.849 \pm 0.64$ \\
\hline Total ash $(\%)$ & $1.252 \pm 0.07$ & $8.05 \pm 0.53$ & $7.257 \pm 0.08$ & $7.652 \pm 0.74$ \\
\hline Carbohydrates ${ }^{* *}(\%)$ & $9.648 \pm 1.8$ & $61.99 \pm 1.33$ & $62.63 \pm 1.93$ & $65.177 \pm 0.6$ \\
\hline Crude fiber $(\%)$ & $3.18 \pm 0.16$ & $20.437 \pm 1.1$ & $17.37 \pm 0.42$ & $18.10 \pm 0.95$ \\
\hline Total sugars $(\%)$ & $1.143 \pm 0.04$ & $7.34 \pm 0.22$ & $4.846 \pm 0.05$ & $5.05 \pm 0.11$ \\
\hline Reducing sugars (\%) & $0.96 \pm 0.06$ & $6.16 \pm 0.42$ & $4.046 \pm 0.03$ & $4.21 \pm 0.43$ \\
\hline Non reducing sugars $(\%)$ & $0.183 \pm 0.03$ & $1.17 \pm 0.07$ & $0.80 \pm 0.06$ & $0.83 \pm 0.04$ \\
\hline Inulin $(\%)$ & $3.492 \pm 0.32$ & $22.44 \pm 0.47$ & $18.877 \pm 0.43$ & $19.67 \pm 0.86$ \\
\hline $\begin{array}{l}\text { Total dietary fibers } \\
(\mathrm{mg} / 100 \mathrm{gm})\end{array}$ & $72.42 \pm 0.76$ & $465.42 \pm 1.4$ & $75.468 \pm 0.86$ & $78.645 \pm 0.76$ \\
\hline Vitamin C (mg/100gm) & $3.75 \pm 0.55$ & $24.1 \pm 0.96$ & $8.00 \pm 0.31$ & $8.33 \pm 0.54$ \\
\hline $\begin{array}{l}\text { Phenolic substances } \\
\text { as (mg tannic acid /100gm) }\end{array}$ & $49.00 \pm 0.76$ & $314.91 \pm 2.11$ & $205.00 \pm 0.21$ & $213.63 \pm 0.66$ \\
\hline Antioxidant activity $(\%)$ & $49.00 \pm 0.95$ & --- & $52.20 \pm 1.87$ & ---- \\
\hline
\end{tabular}

Mean \pm SD

$\mathrm{A}=$ wet weight basis

$\mathrm{B}=$ Dry weight basis

*** By difference

Table 3. Mineral content of fresh GOM and DGF

\begin{tabular}{lcc}
\hline $\begin{array}{l}\text { Element } \\
\text { ppm* }\end{array}$ & ${ }^{* *}$ Fresh GOM & DGF \\
\hline $\mathrm{Na}$ & $1573.84 \pm 5.4$ & $436.85 \pm 3.6$ \\
$\mathrm{~K}$ & $33352.58 \pm 2.3$ & $9257.54 \pm 1.9$ \\
$\mathrm{Ca}$ & $267.16 \pm 0.55$ & $74.16 \pm 0.65$ \\
$\mathrm{Mg}$ & $30.96 \pm 0.43$ & $8.59 \pm 0.34$ \\
$\mathrm{Fe}$ & $34.58 \pm 0.51$ & $9.6 \pm 0.62$ \\
$\mathrm{Cu}$ & $8.94 \pm 0.08$ & $2.48 \pm 0.07$ \\
$\mathrm{Mn}$ & $4.41 \pm 0.07$ & $1.22 \pm 0.05$ \\
$\mathrm{Zn}$ & $3.73 \pm 0.07$ & $1.04 \pm 0.04$ \\
$\mathrm{Cd}$ & $\mathrm{ND}$ & $\mathrm{ND}$ \\
$\mathrm{Pd}$ & $6.8 \pm 0.13$ & $1.86 \pm 0.03$ \\
\hline
\end{tabular}

*Dry weight basis

** Mean \pm SD

*** Not detected 
9

8

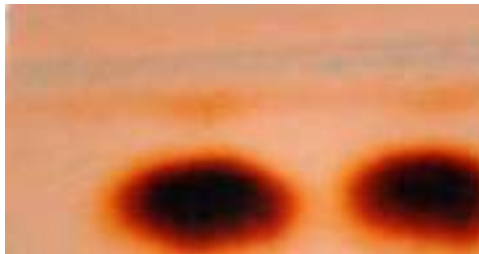

7

6

5

4

3

2

1

Fig 3. Thin layer chromatogram of total lipids ofGOM

Coating material: silica gel G Merk type 60

Solvent system:- Petroliun ether: diethyl ether: glacial acetic acid (70:30:2)

Detection: Exposure to iodine vapour

1: Polar lipids

2: Monoacylglycerols

3: 1,2 and 2,3 diacylglycerols

4: Sterols

5: 1,3 diacylglycerols

6: Unknown
7: Free Fatty acids

8: Triacylglycerols

9: Hydrocarbons and sterolesters 
Table 4. Fatty acid composition of the total lipids of fresh GOM

\begin{tabular}{lc}
\hline Fatty acid & $(\boldsymbol{\%})^{*}$ \\
\hline Myristic $\left(\mathrm{C}_{14: 0}\right)$ & $1.96 \pm 0.031$ \\
Palmitic $\left(\mathrm{C}_{16: 0}\right)$ & $29.96 \pm 0.32$ \\
Palmitoleic $\left(\mathrm{C}_{16: 1}\right)$ & $1.48 \pm 0.03$ \\
Stearic $\left(\mathrm{C}_{18: 0}\right)$ & $2.48 \pm 0.1$ \\
Oleic $\left(\mathrm{C}_{18: 1}\right)$ & $16.46 \pm 0.27$ \\
Linoleic $\left(\mathrm{C}_{18: 2}\right)$ & $39.20 \pm 0.31$ \\
Linolenic $\left(\mathrm{C}_{18: 3}\right)$ & $5.89 \pm 0.04$ \\
Arachidic $\left(\mathrm{C}_{20: 0}\right)$ & $1.79 \pm 0.05$ \\
Others & $0.78 \pm 0.02$ \\
Total saturated $(\mathrm{s})$ & $36.19 \pm 0.31$ \\
Total unsaturated $(\mathrm{u})$ & $63.03 \pm 0.42$ \\
u/s ratio & $1.74 \pm 0.23$ \\
\hline
\end{tabular}

Mean \pm SD

\section{Weight loss of fresh cut GOM during refrigeration:-}

Fig. (4) shows the weight loss (\%) of fresh cut of GOM during refrigeration storage. The recorded temperature and $\mathrm{RH}$ during the period of storage were $10{ }^{0} \mathrm{C}$ and $70 \%$ respectively. There was a gradual increase in weight loss with the time. It reached about 12.0, 17.0, 26.6 and $33.5 \%$ after one, two, three weeks and one month, respectively. The weight loss could be attributed to the loss of water from GOM strips which may be attributed to the decrease ability of proteins to hold the water. Some dryness in the texture of fresh cut GOM was observed with the time elapsed. This dryness could be correlated with the weight loss. Fig (5) shows the visual changes in colour and general appearance of fresh cut GOM during refrigeration storage at $10{ }^{\circ} \mathrm{C}$ and $70 \% \mathrm{RH}$. At the beginning (zero time), the original colour was creamy white then changed gradually with the time elapsed into different degrees of brown colour. The changes in colour of GOM strips may be attributed to the increase activity of oxidoreductase enzyme. A growth of fungi has been observed having blue greenish colour on some strips of fresh cut GOM. This fungi was isolated and identified as Penicillium sp.(Fig.6). The growth of fungi was taken to be an indicator of the end shelf life of fresh cut GOM. Accordingly, the shelf life of fresh cut GOM under refrigeration storage at $10{ }^{\circ} \mathrm{C}$ was less than 12 days.

\section{Effect of storage on organoleptic properties of frozen cubes of GOM:-}

Table (5) summarizes the organoleptic properties of frozen cubes of GOM. It was obvious that panelists accepted the frozen cubes of GOM even after storage for 3 months, Slight significant differences were noticed in taste, odour, texture as well as overall acceptability after 2 months of storage at $-18{ }^{0} \mathrm{C}$. The overall acceptability of frozen cubes varied between 6.93 to 7.66 .

\section{Organoleptic properties of GOM jam:-}

Table (6) and Fig (7) illustrate the organoleptic properties and the appearance of GOM jam. It can be concluded that no significant differences were noticed in colour, taste, odour, texture and overall acceptability of GOM jam (control) or those flavoured with rose and banana flavouring agents. It was obvious that panelists accepted the aforementioned products.

\section{Organoleptic properties of fruit salads containing GOM:-}

Table (7) and Fig (8) summarize the organoleptic properties and the general appearance of fruit salads containing GOM. It was obvious that panelists accepted all the fruit salad products prepared from GOM and the other fruits. Except colour and taste of peach, nectarine and husk tomato, no significant differences were noticed in the other studied parameters. Mixing GOM and other fruits to prepare fruit salads did not affect the acceptability of the final product.

The results in Table (8) show that total soluble solids of GOM liquor were lower that those of the other fruits which varied from 14.0 to 16.8 Brix. On the other hand, $\mathrm{pH}$ value ranged between 4.34 to 4.63 which was slightly higher than that of GOM liquor. Further, titratable acidity differed widely $(0.323-0.621 \%)$ which was slightly higher than that of GOM liquor. This is an indication that TSS, $\mathrm{pH}$ and titratable acidity are based on fruit variety utilized in the present study. In general GOM liquor had the lowest TSS. pH and titratable acidity in comparison with the other fruits. 


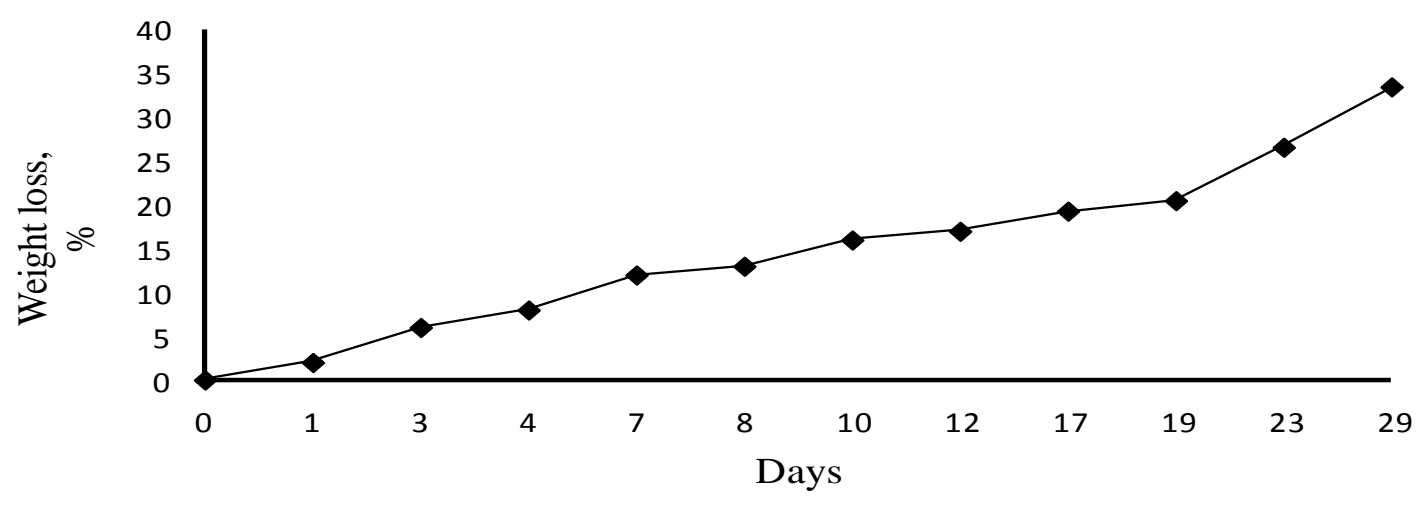

Fig.4. Weight loss of fresh cut GOM during refrigeration
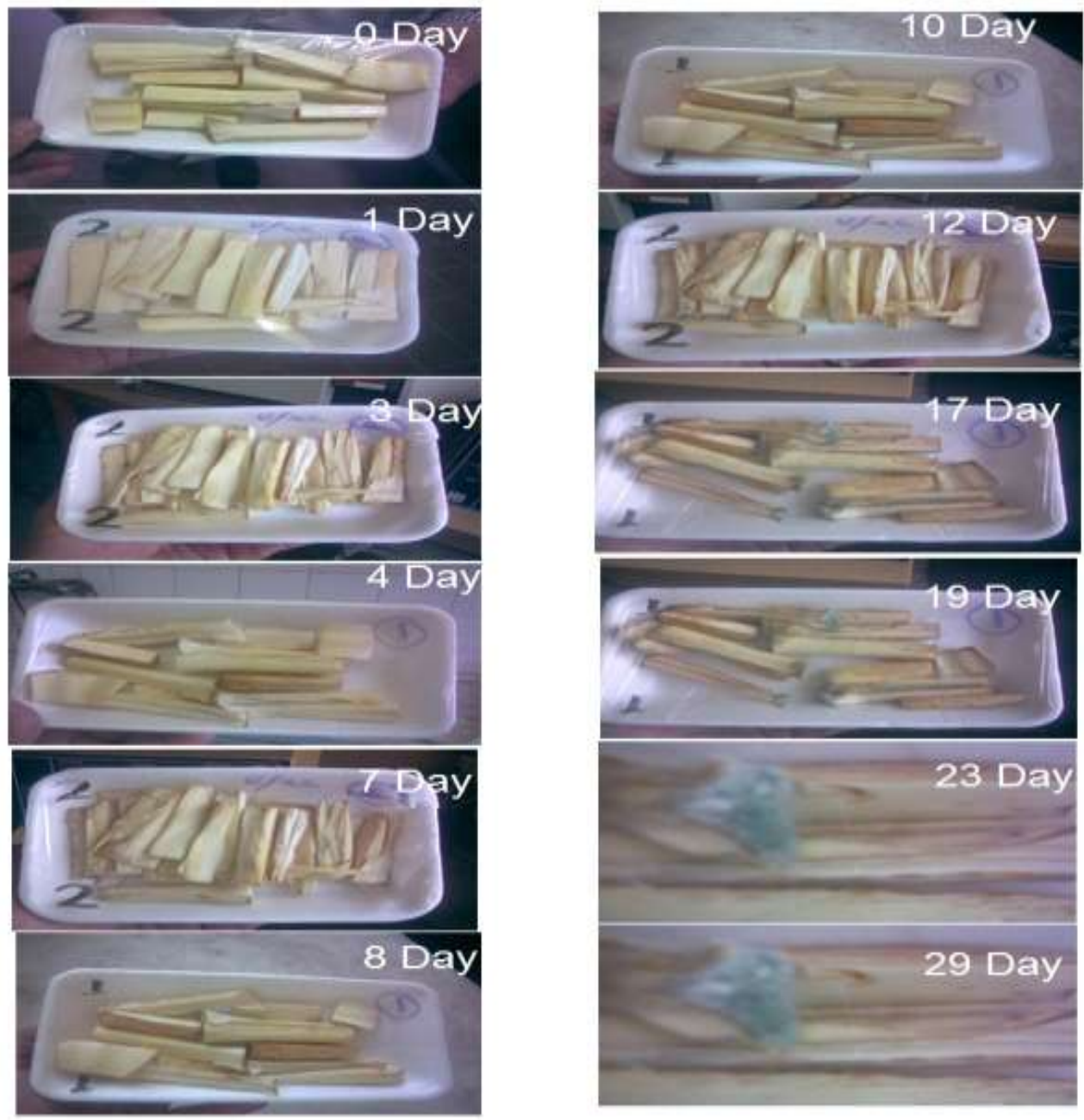

Fig .5. The visual changes in colour and general appearance of fresh cut GOM during refrigerated storage at $10{ }^{\circ} \mathrm{C}$ and $70 \% \mathrm{RH}$ 

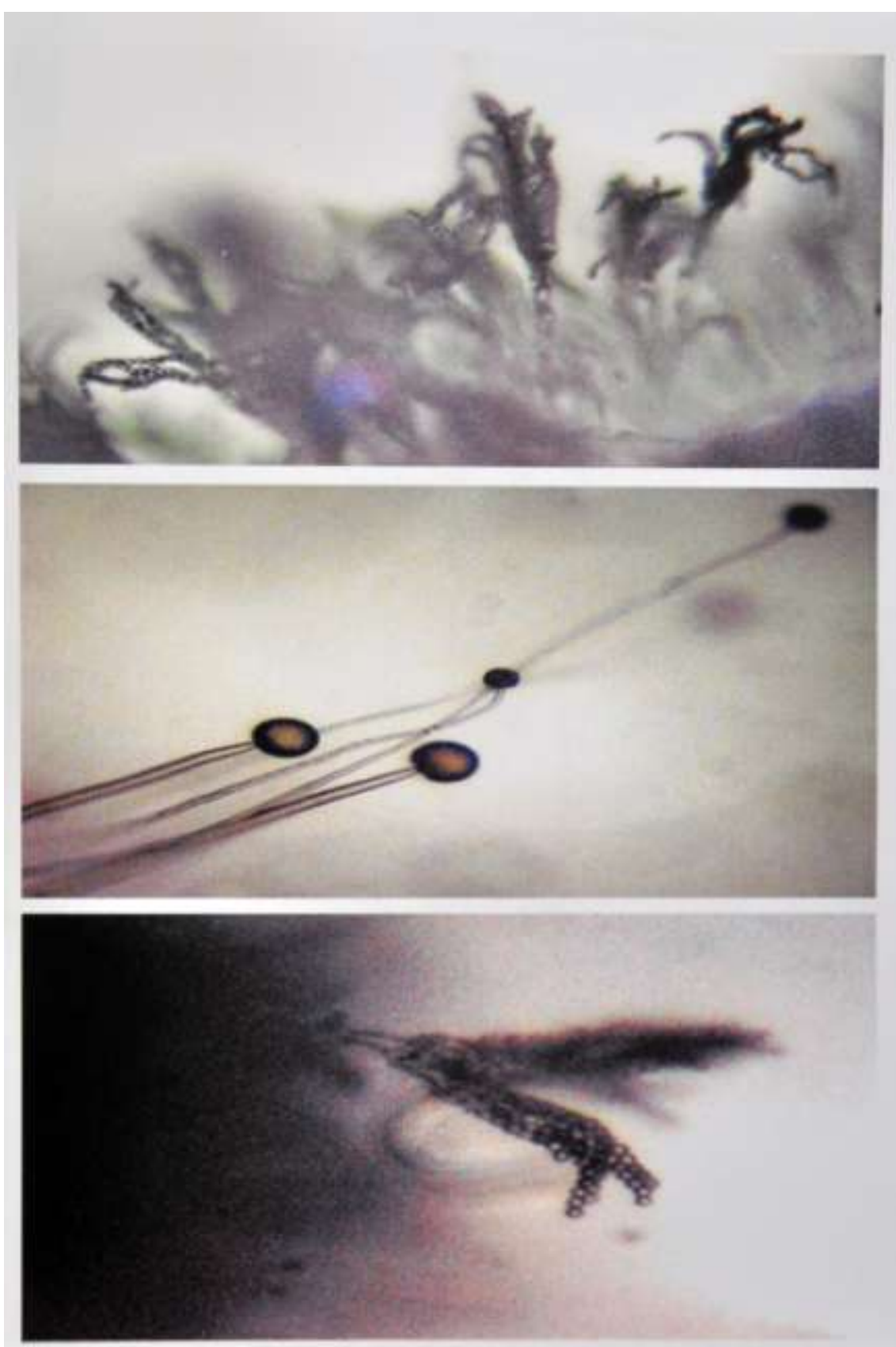

Fig. 6. Fungi (Penicillium sp.) grown on strips of fresh cut GOM after 12 days of refrigerated storage

Table 5. Effect of storage on organoleptic properties of frozen cubes of GOM

\begin{tabular}{lcccc}
\hline Character & \multicolumn{3}{c}{ Storage period (month) $^{*}$} \\
& Control & $\mathbf{1}$ & $\mathbf{2}$ & $\mathbf{3}$ \\
\hline Colour & $8.13^{\mathrm{a}}$ & $7.86^{\mathrm{a}}$ & $7.8^{\mathrm{a}}$ & $7.8^{\mathrm{a}}$ \\
Taste & $7.66^{\mathrm{a}}$ & $7.4^{\mathrm{a}}$ & $7.26^{\mathrm{ab}}$ & $7.2^{\mathrm{ab}}$ \\
Odour & $7.66^{\mathrm{a}}$ & $7.33^{\mathrm{ab}}$ & $7.26^{\mathrm{ab}}$ & $7.06^{\mathrm{b}}$ \\
Texture & $7.66^{\mathrm{a}}$ & $7.00^{\mathrm{b}}$ & $6.93^{\mathrm{b}}$ & $6.93^{\mathrm{b}}$ \\
Overall acceptability & $7.66^{\mathrm{a}}$ & $7.00^{\mathrm{b}}$ & $6.93^{\mathrm{b}}$ & $6.93^{\mathrm{b}}$ \\
\hline Means in a row not sharing the same superscript are significantly different at P $\leq 0.05$ & & &
\end{tabular}




\section{Table 6. Organoleptic evaluation of GOM Jam}

\begin{tabular}{lccc}
\hline Character & \multicolumn{3}{c}{ Jam product } \\
& $\mathbf{1}$ & $\mathbf{2}$ & $\mathbf{3}$ \\
\hline Colour & $8.26^{\mathrm{a}}$ & $8.2^{\mathrm{a}}$ & $8.06^{\mathrm{a}}$ \\
Taste & $8.66^{\mathrm{a}}$ & $8.26^{\mathrm{a}}$ & $8.13^{\mathrm{a}}$ \\
Odour & $8.33^{\mathrm{a}}$ & $8.13^{\mathrm{a}}$ & $8.07^{\mathrm{a}}$ \\
Texture & $8.33^{\mathrm{a}}$ & $8.13^{\mathrm{a}}$ & $8.06^{\mathrm{a}}$ \\
Overall acceptability & $8.33^{\mathrm{a}}$ & $8.13^{\mathrm{a}}$ & $8.06^{\mathrm{a}}$ \\
\hline
\end{tabular}

Means in a row not sharing the same superscript are significantly different at $\mathrm{P} \leq 0.05$

1- control

2- GOM + rose flavouring agent

3- GOM+ banana flavouring agent

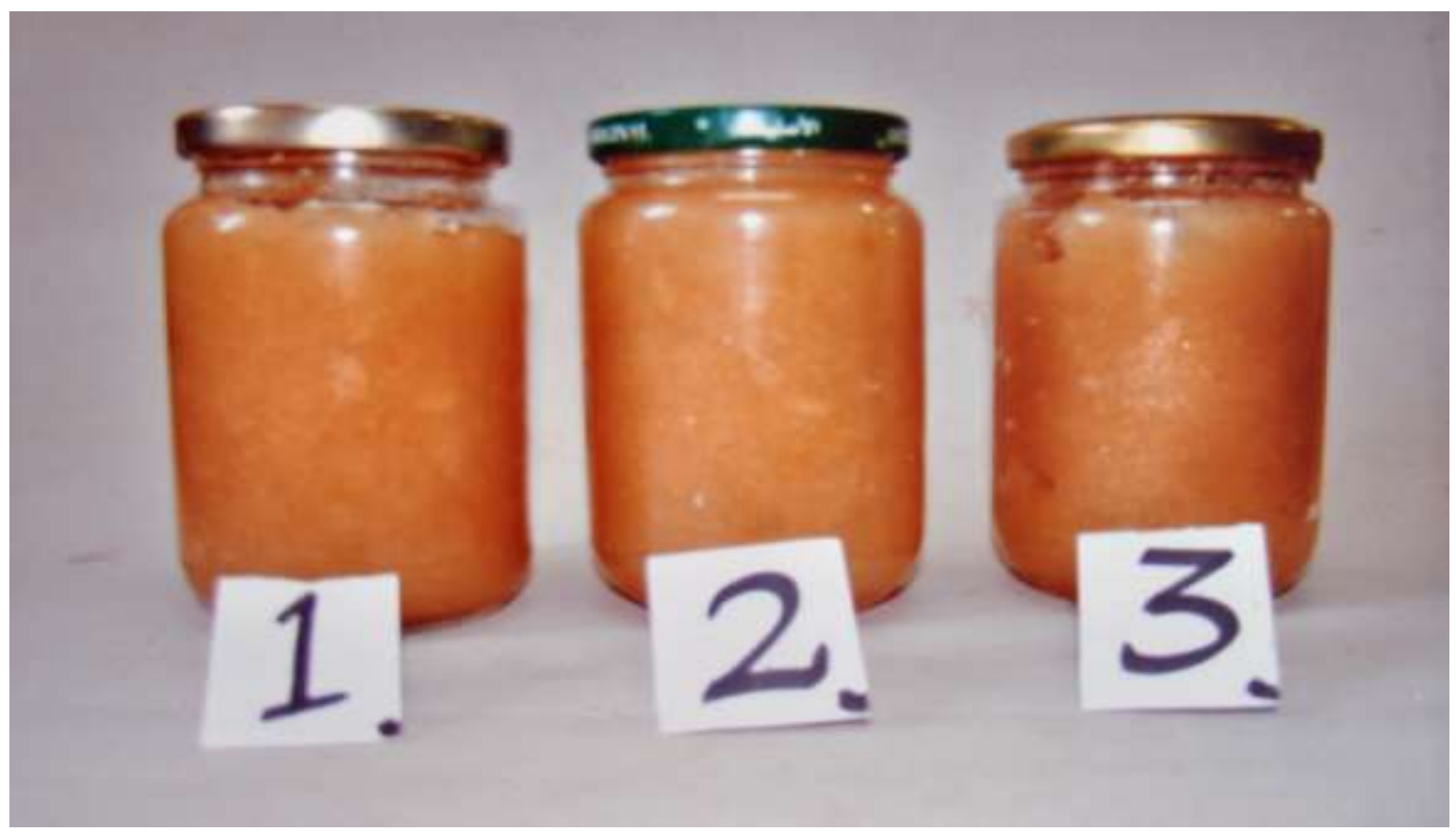

Fig. 7. General appearance of GOM jam

1- Control

2- GOM+ rose flavouring agent

3- GOM+ banana flavouring agent

\section{Table 7. Organoleptic evaluation of fruit salads containing GOM cubes}

\begin{tabular}{lccccccc}
\hline Character & \multicolumn{7}{c}{ fruit salads } \\
& $\mathbf{1}$ & $\mathbf{2}$ & $\mathbf{3}$ & $\mathbf{4}$ & $\mathbf{5}$ & $\mathbf{6}$ & $\mathbf{7}$ \\
\hline Colour & $8.33^{\mathrm{a}}$ & $8.33^{\mathrm{a}}$ & $8.33^{\mathrm{a}}$ & $8.13^{\mathrm{ab}}$ & $8.13^{\mathrm{ab}}$ & $8.00^{\mathrm{ab}}$ & $7.73^{\mathrm{b}}$ \\
Taste & $8.46^{\mathrm{a}}$ & $8.06^{\mathrm{ab}}$ & $8.06^{\mathrm{ab}}$ & $8.00^{\mathrm{ab}}$ & $7.93^{\mathrm{b}}$ & $7.93^{\mathrm{b}}$ & $7.93^{\mathrm{b}}$ \\
Odour & $8.20^{\mathrm{a}}$ & $8.13^{\mathrm{a}}$ & $8.06^{\mathrm{a}}$ & $8.06^{\mathrm{a}}$ & $8.00^{\mathrm{a}}$ & $8.00^{\mathrm{a}}$ & $8.00^{\mathrm{a}}$ \\
Texture & $8.26^{\mathrm{a}}$ & $8.27^{\mathrm{a}}$ & $8.06^{\mathrm{a}}$ & $8.00^{\mathrm{a}}$ & $8.00^{\mathrm{a}}$ & $7.93^{\mathrm{a}}$ & $7.86^{\mathrm{a}}$ \\
Overall acceptability & $8.40^{\mathrm{a}}$ & $8.20^{\mathrm{a}}$ & $8.20^{\mathrm{a}}$ & $8.13^{\mathrm{a}}$ & $8.66^{\mathrm{a}}$ & $8.00^{\mathrm{a}}$ & $8.00^{\mathrm{a}}$ \\
\hline
\end{tabular}

Means in a row not sharing the same superscript are significantly different at $\mathrm{P} \leq 0.05$

1- Contol (GOM cubes only)

2- GOM cubes+ loquat fruit

3- GOM cubes + strawberry

4- GOM cubes +peach

5- GOM cubes + nectarine

6- GOM cubes + husk tomato

7- GOM cubes + cocktail of the above fruits 


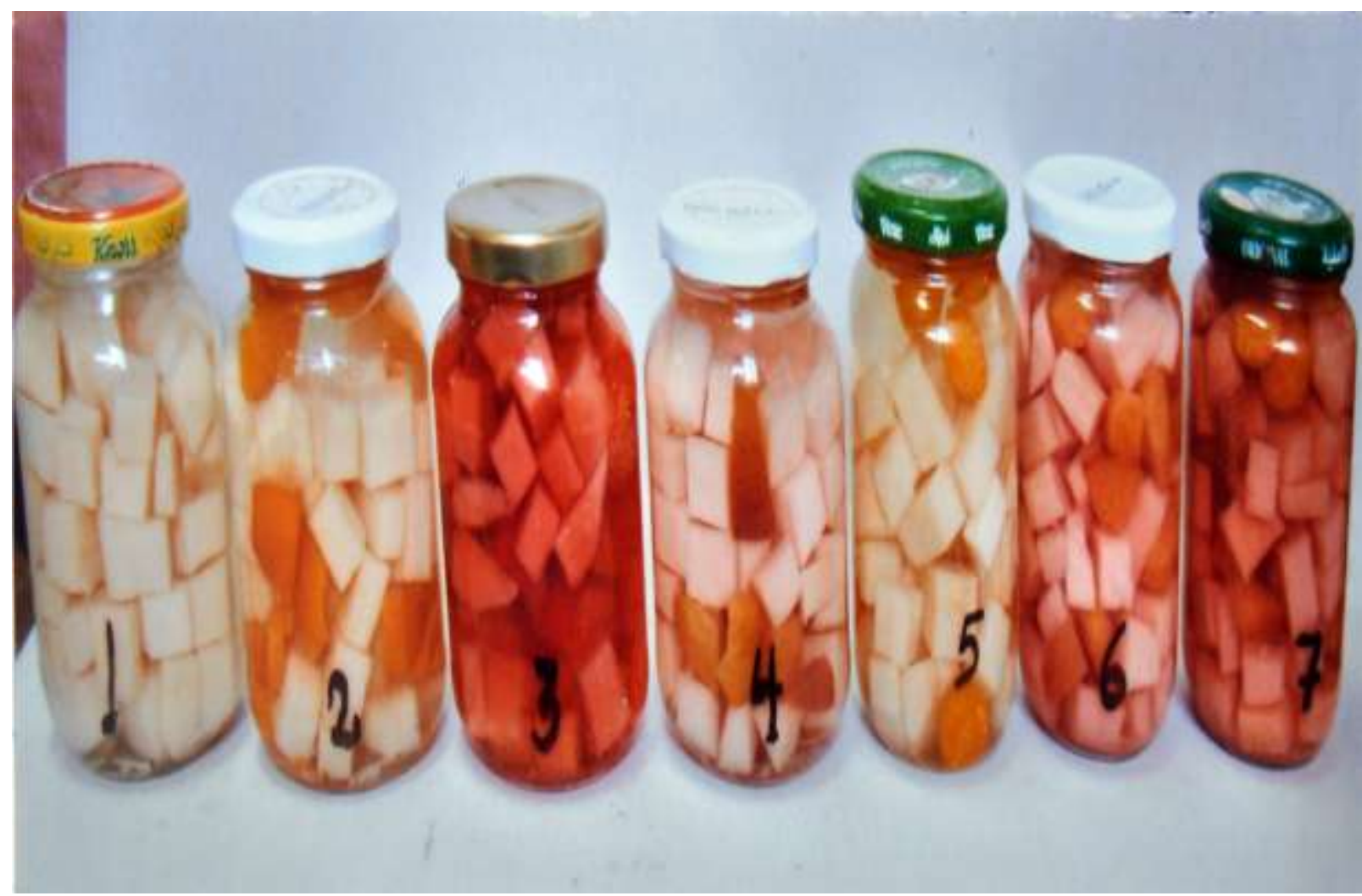

Fig.8. General appearance of fruit salads containing GOM

1- Contol (GOM cubes only)

2- GOM cubes+ loquat fruit

3- GOM cubes + strawberry

4- GOM cubes +peach

5- GOM cubes +nectarine

6- GOM cubes + husk tomato

7- GOM cubes + cocktail of the above fruits

Table 8. Total soluble solids $\left(\mathrm{Brix}^{0}\right)$, $\mathrm{pH}$ and titratable acidity of liquor of fruit salads containing GOM

\begin{tabular}{llcc}
\hline Treatment $^{*}$ & $\begin{array}{c}\text { TSS \% } \\
\text { (Brix) }\end{array}$ & pH & $\begin{array}{c}\text { Titratable acidity } \\
\text { (gm/100gm solution) }\end{array}$ \\
\hline 1 & $11.20 \pm 0.36$ & $4.20 \pm 0.08$ & $0.299 \pm 0.03$ \\
2 & $15.10 \pm 0.27$ & $4.34 \pm 0.06$ & $0.323 \pm 0.06$ \\
3 & $14.00 \pm 0.07$ & $4.52 \pm 0.05$ & $0.37 \pm 30.08$ \\
4 & $14.80 \pm 0.12$ & $4.57 \pm 0.04$ & $0.495 \pm 0.02$ \\
5 & $16.60 \pm 0.26$ & $4.60 \pm 0.06$ & $0.621 \pm 0.03$ \\
6 & $16.80 \pm 0.31$ & $4.63 \pm 0.08$ & $0.537 \pm 0.04$ \\
7 & $16.60 \pm 0.11$ & $4.60 \pm 0.03$ & $0.530 \pm 0.02$ \\
\hline
\end{tabular}

Mean \pm SD

1 : Control (GOM) only

2: Control + loquat fruit

3: Control + strawberry

4: Control + peach

5: Control + nectarine

6: Control + husk tomato

7: Control + cocktail of the above fruits 
Organoleptic properties of fruit salads liquor containing GOM:-

The organoleptic attributes of liquor of fruit salads containing GOM are illustrated in Table (9). Generally all the attributes including taste, colour, odour, and overall acceptability were over the numerical value of 7 (like moderately). These findings indicated that all the parameters studied were very good accepted by the panelists. The results also showed that slight significant differences were noticed between the liquor obtained from the different prepared fruit salads.

Organoleptic properties of biscuits containing DGF:-

The organoleptic attributes of aniseed and ammonium biscuits containing DGF are presented in Tables (10 and 11). Generally all the attributes including colour, taste, odour, texture and overall acceptability were over the numerical value of 7 (like moderately). These findings indicated that all the parameters studied were very good accepted by the panelists especially biscuits containing 2.5 and $5 \%$ DGF .Slight significant differences were noticed in the organoleptic attributes especially in aniseed biscuit containing 7.5\% DGF. Both biscuits containing $7.5 \%$ DGF still well accepted by the panelists.

Organoleptic properties of Chocolate chip cookies containing DGF : -

Table (12) summarizes the organoleptic properties, while Fig. (9) illustrates the general appearance of chocolate chip cookies containing dehydrated DGF . According to the recorded data it was obvious that panelists accepted this product and the overall acceptability was described by panelists as like very much .Comparing with the previous products it can be concluded that chocolate chip cookies are very accepted by the panelists.

Organoleptic properties of belellah and rice pudding containing DGF:-

The organoleptic attributes of bellellah and rice pudding products containing different concentrations (2.5, 5.0 and $7.5 \%)$ of DGF are illustrated in Tables (13 and 14). According to the obtained data, the overall acceptability of these products decreased with increasing the amount of DGF. Slight significant differences were noticed between the control samples and those contained the different concentrations of DGF.

\section{Table 10. Organoleptic evaluation of aniseed biscuits containing DGF}

\begin{tabular}{lcccc}
\hline Character & \multicolumn{4}{c}{ Treatments } \\
& $\mathbf{1}$ & $\mathbf{2}$ & $\mathbf{3}$ & $\mathbf{4}$ \\
\hline Colour & $8.66^{\mathrm{a}}$ & $8.40^{\mathrm{a}}$ & $7.86^{\mathrm{b}}$ & $7.66^{\mathrm{b}}$ \\
Taste & $8.20^{\mathrm{a}}$ & $8.00^{\mathrm{ab}}$ & $7.40^{\mathrm{bc}}$ & $7.07^{\mathrm{c}}$ \\
Odour & $8.40^{\mathrm{a}}$ & $7.86^{\mathrm{b}}$ & $7.73^{\mathrm{b}}$ & $7.73^{\mathrm{b}}$ \\
Texture & $8.06^{\mathrm{a}}$ & $8.00^{\mathrm{a}}$ & $7.93^{\mathrm{a}}$ & $7.73^{\mathrm{a}}$ \\
Overall acceptability & $8.53^{\mathrm{a}}$ & $8.00^{\mathrm{b}}$ & $7.93^{\mathrm{b}}$ & $7.86^{\mathrm{b}}$ \\
\hline
\end{tabular}

Means in a row not sharing the same superscript are significantly different at $\mathrm{P} \leq 0.05$

1- Control

2- $2.5 \% \mathrm{DGF}$

3- $5.0 \%$ DGF

4- $7.5 \%$ DGF

\section{Table 11. Organoleptic evaluation of ammonium biscuits containing DGF}

\begin{tabular}{lcccc}
\hline Character & \multicolumn{4}{c}{ Treatments } \\
& $\mathbf{1}$ & $\mathbf{2}$ & $\mathbf{3}$ & $\mathbf{4}$ \\
\hline Colour & $8.93^{\mathrm{a}}$ & $8.53^{\mathrm{a}}$ & $8.13^{\mathrm{ab}}$ & $7.93^{\mathrm{b}}$ \\
Taste & $8.26^{\mathrm{a}}$ & $8.13^{\mathrm{a}}$ & $8.06^{\mathrm{a}}$ & $7.80^{\mathrm{b}}$ \\
Odour & $8.22^{\mathrm{a}}$ & $8.20^{\mathrm{a}}$ & $8.00^{\mathrm{a}}$ & $7.60^{\mathrm{b}}$ \\
Texture & $8.86^{\mathrm{a}}$ & $8.40^{\mathrm{a}}$ & $8.20^{\mathrm{b}}$ & $7.93^{\mathrm{b}}$ \\
Overall acceptability & $8.40^{\mathrm{a}}$ & $8.40^{\mathrm{a}}$ & $8.06^{\mathrm{a}}$ & $8.00^{\mathrm{a}}$ \\
\hline
\end{tabular}

Means in a row not sharing the same superscript are significantly different at $\mathrm{P} \leq 0.05$

1-Control

$2-2.5 \%$ DGF

3- 5.0\% DGF

4- $7.5 \%$ DGF 
Table 12. Organoleptic evaluation of chocolate chip cookies containing DGF

\begin{tabular}{lc}
\hline Character & Value \\
\hline Colour & $8.47 \pm 0.74$ \\
Taste & $8.73 \pm 0.59$ \\
Odour & $8.67 \pm 0.62$ \\
Texture & $8.47 \pm 0.54$ \\
Overall acceptability & $8.53 \pm 0.52$ \\
\hline
\end{tabular}

Mean \pm SD

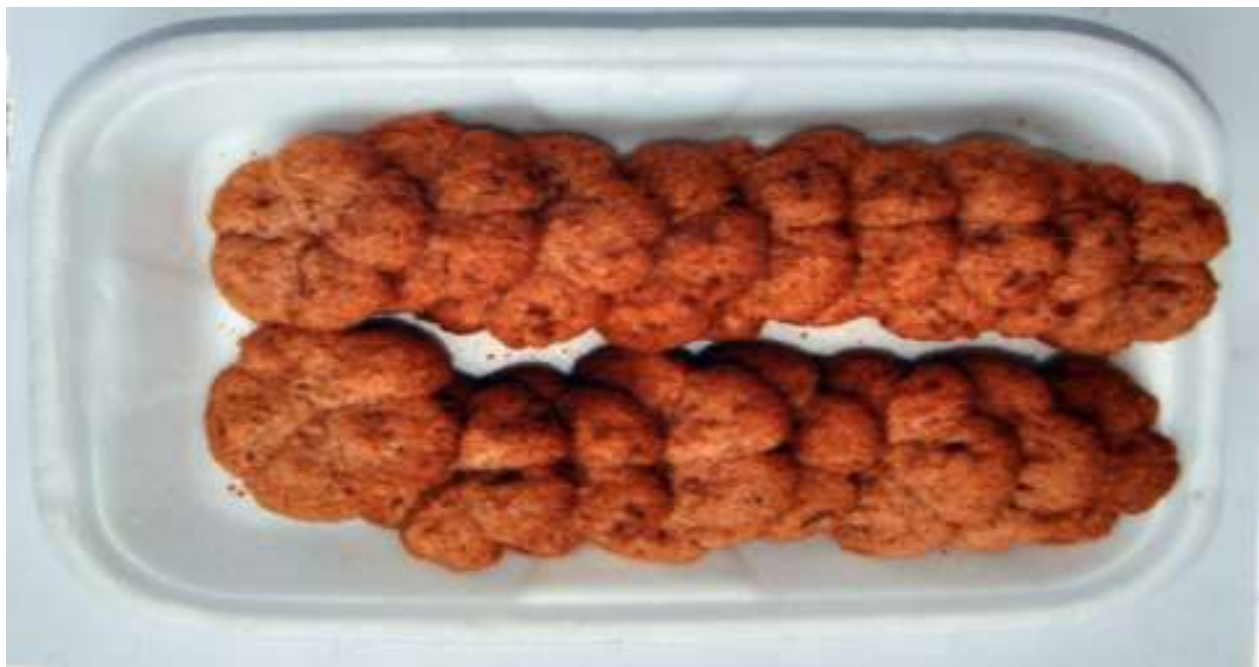

Fig. 9. General appearance of chocolate chip cookies containing DGF

Table 13. Organoleptic evaluation of belellah product containing DGF

\begin{tabular}{lcccc}
\hline Character & \multicolumn{4}{c}{ Treatments } \\
& $\mathbf{1}$ & $\mathbf{2}$ & $\mathbf{3}$ & $\mathbf{4}$ \\
\hline Colour & $8.00^{\mathrm{a}}$ & $7.73^{\mathrm{b}}$ & $7.40^{\mathrm{bc}}$ & $6.93^{\mathrm{c}}$ \\
Taste & $8.80^{\mathrm{a}}$ & $7.80^{\mathrm{b}}$ & $7.13^{\mathrm{c}}$ & $6.93^{\mathrm{c}}$ \\
Odour & $8.60^{\mathrm{a}}$ & $7.80^{\mathrm{b}}$ & $7.06^{\mathrm{c}}$ & $6.80^{\mathrm{c}}$ \\
Texture & $8.73^{\mathrm{a}}$ & $7.66^{\mathrm{b}}$ & $7.53^{\mathrm{b}}$ & $7.46^{\mathrm{b}}$ \\
Overall acceptability & $8.60^{\mathrm{a}}$ & $7.80^{\mathrm{b}}$ & $7.20^{\mathrm{c}}$ & $7.06^{\mathrm{c}}$ \\
\hline
\end{tabular}

Means in a row not sharing the same superscript are significantly different at $\mathrm{P} \leq 0.05$

1- Control

2- $2.5 \%$ DGF

3- $5.0 \% \mathrm{DGF}$

4- $7.5 \%$ DGF

\section{Table 14. Organoleptic evaluation of rice pudding containing DGF}

\begin{tabular}{lcccc}
\hline Character & \multicolumn{4}{c}{ Treatments } \\
& $\mathbf{1}$ & $\mathbf{2}$ & $\mathbf{3}$ & $\mathbf{4}$ \\
\hline Colour & $8.86^{\mathrm{a}}$ & $7.53^{\mathrm{b}}$ & $6.73^{\mathrm{c}}$ & $6.13^{\mathrm{d}}$ \\
Taste & $9.06^{\mathrm{a}}$ & $7.86^{\mathrm{b}}$ & $6.93^{\mathrm{c}}$ & $6.53^{\mathrm{c}}$ \\
Odour & $8.93^{\mathrm{a}}$ & $8.26^{\mathrm{b}}$ & $7.00^{\mathrm{c}}$ & $6.80^{\mathrm{c}}$ \\
Texture & $8.86^{\mathrm{a}}$ & $7.80^{\mathrm{b}}$ & $7.46^{\mathrm{b}}$ & $7.40^{\mathrm{b}}$ \\
Overall acceptability & $9.23^{\mathrm{a}}$ & $7.33^{\mathrm{b}}$ & $7.33^{\mathrm{b}}$ & $6.80^{\mathrm{c}}$ \\
\hline
\end{tabular}

Means in a row not sharing the same superscript are significantly different at $\mathrm{P} \leq 0.05$

1- Control

2- $2.5 \% \mathrm{DGF}$

3- $5.0 \%$ DGF

4- $7.5 \%$ DGF 
In spits of these findings all the products were still accepted by the panelists even those containing the higher percentages of DGF.

Based on the results in this study, it can be concluded that both fresh GOM and its dehydrated flour are high in its dietary fiber, inulin, minerals especially $\mathrm{K}, \mathrm{Na}$ and $\mathrm{Ca}$ and contained significant amounts of $\mathrm{W}_{6}$ and $\mathrm{W}_{3}$ fatty acids and can be used as a good source of natural antioxidants. In addition, the different products prepared from fresh GOM and its dehydrated flour were highly acceptable by the panelists.

\section{ACKNOWLEDGMENT}

We wish to express our deepest gratitude to both Dr. Ahmed Rafik El-Mahdy and Dr. Osama R.Abu-Samaha, professors of Food Science and Technology, Faculty of Agriculture, Alexandria University for their kind encouragement and generous help and cooperation from the start to the end of this study.

\section{REFERENCES}

Abdalla, M.Y.; Abo-El-Sooud, A.A.;Ammar, M.E.F.Rashid,M.F and Saber, F.M.M. (2008). Palm tree: Agricutuure and Service. (In Arabic) Agriculture Technology Report, Ministry of Agriculture, A.R.E.

Abd-Elsalam F.F.(2011). Utilization of corn in some gluten free food products.M.Sc. Thesis.Food Science and Technology Department, Faculty of Agriculture, Alex. University, Egypt.

Abou-Gharbia, H.A. and Abou-Tour, E.M. (2001).Properties and processing of husk tomato Physalis pruinosal. Minofiya.J.Agric. Res. 26: 761-781.

A.O.A.C.(1998). Association of Official Analytical Chemists. Official methods of analysis of the Association of Official Analytical Chemists, Washington ,4,DU,USA.

Askar, D.H.S.(1991). Chemical and Technological Studies on Sunflower Seeds. M.Sc Thesis,Food Sceince and Technology. Department, Faculty of Agriculture, Alex.University, Egypt

Farag, K.M. (2004). Palm tree: Science, Culture and Tradition (In Arabic) Zayed Center for Tradition and History. UAE.

Fogliano, V.; Verde, V.; Randazzo, G. and Ritieni, A. (1999). Method for measuring antioxidant activity and its application to monitoring antioxidant capacity of wines. J. Agric. Food Chem., 47:1035-1040

Folch, J.; Lees,M. and Stanley, G.H.(1957). A simple method for the isolation and purification of total lipid from animal tissues. J.Biol.Chem., 266:479-509.

Galeazi,M.; Sgarbierion, C. and Constantinides, S.(1981). Isolation, purification and physicochemical characterization of polyphenol oxidase (PPO) from a Dwarf variety of banana .J. Food Sci.46:150-155

George,M. and Agrios, P. (1978). Plant pathology, $2^{\text {nd. }}$ Acadimic press, New York.
Gerhardt, P., Marray, R.G.E.; Castitlow,R.N.;Nester,E.W.; Wood, W.A. and Philips, G.B.(1994). Manual of method for general bacteriology. Washinton:American Society for microbiology .

Gil, M.I.;Tomas-Barberan, F.A.;Hess-Pierce,B. and Kader, A.A. (2002) Antioxidant capacities, phenolic compounds,carotenoids and vitamin $\mathrm{C}$ content of nectarine, peach and plum cultivars from California. J. Agric.Food Chem.50: 4976-4982.

Gupta,A.K.;Kaur,M. and Singh, R. (1993). Potential medical and nutritional uses of chicory roots and inulin. In Fuchs,A.Inulin and inulin containing crops (pp 359-365) Amesterdam, Elsevier

Hellwege,E.M., Czapla, S., Jahnke,A., Willmitzer,L., and Heyer,A.G. (2000). Transgenic potato (Solanum tuberosum) tubers synthesize the full spectrum of inulin molecules naturally occurring in globe artichoke (Cynara scolymus) roots. Proceedings of the National Academy of Sciences, USA,97: 8699-8704.

Jiratanan, T. and Liu, R.H. (2004). Antioxidant activity of processed table beets (Beta vulgaris var, Conditiva) and green beans (Phaseolus vulgaris .L) .J. Agric.Food Chem., 52:2659-2670.

Kirk,R.S. and Sawyer, R.(1991). Person's composition and analysis of foods. Ninth Edition Longman Singapore Publishers (pte) Ltd.

Kramer, A. and Twigg, B.A. (1970). Quality control for the food industry $3^{\text {th }}$ Ed. AVI Publishing Co. Westport Conn. London. England.

Lamers, R.J.A.N.; Wessels, E.C.H.H.; Sandt, J.J.M.; Venema, K.; Schaafsma, G.; Greef, J. and Nessebrooij, J.H.J.(2003) . A pilot study to investigate effects of inulin on Caco-2 cells through in vitro metabolic fingerprinting .J. Nutr. 133: 3080-3084.

Mangold, H.K. and Malins, D.C. (1960) . Fractionation of fats, oils and waxes on thin layers of silicic acid. J.Am.Oil Chem.Soc., 37: 383-385.

Naczk, M. and Shahidi, F.(1989). The effect of methanol ammonia-water treatment on the content of phenolic acids of canola. Food Chem., 31:159-164.

Olmos, E.; Piquerces, A.; Martinez-Solano, J.R. and Hellin, E. (1997). The subcellular localization of peroxidase and the implication of oxidative stress in hyperhydrated leaves of regenerated carnation plants. Plant Sci., 130: 97-105 .

Plummer, T.D. (1978). An Introduction to Practical Biochemistry. Mc. Graw Hill Book Company (UK)Limited. pp.273.

Pool Zobel, B.L. (2005). Inulin-type fructans and reduction in colon cancer risk: Review of experimental and human data. British J. of Nutr.,93:73-90.

Prosky, L.; Asp, N.G.;Furda, I.; De Vries, J.W.;Schweizer, T.F. and Harland, B.F(1985). Determination of total dietary fiber in foods and food products: Collaborative study. J. Assoc. Off. Anal.Chem.68: 677679. 
Rahma, E.H. and Abd El-Aal, M.H.(1988).Chemical characterization of peach kernel oil and protein. Functional properties, in-vitro digestibility and amino acid for the flour. Food Chem.. 27:31-43.

Ranganna, S.(1977). Manual of Analysis of Fruit and Vegetable Products.Mc Grow-Hill Pub.Co.LTD., New Delhi .

Steel, R.G. and Torrie, J.H. (1980).Principles and Procedures of Statistics. $2^{\text {nd }}$ Ed Mc Graw Hill, New York, USA.

Sylvester, O. and Avalos, G. (2009). Illegal palm heart (Geonoma edulis) harvest in Costa Rican national parks: patterns of consumption and extraction. Economic Botany. 63: 179-189.
Takeoka, G.R.; Dao, L.; Flessa, S.;Gillespie, D.M.;Jewell, W.T.,Huebner,B.;Bertow, D. and Ebeler, S.E. (2001). Processing effect on lycopene content and antioxidant activity of tomatoes. J.Agric.Food Chem., 49:3713-3717.

Trepel ,F.(2004). Dietary fiber: more than a matter of dietetics. 1. Compounds, properties, physiological effects. Wien Klin Wochenschr. 116: 465-476.

Wada, L. and Ou, B. (2002). Antioxidant activity and phenolic content of oregon caneberries. J.Agric.Food Chem., 50:3495-3500.

Van Waes, C., Baert, J., Carlier, L., and Van Bockstaele, E., (1998).A rapid determination of the total sugar content and the average inulin chain length in root of chicory (Cichorium intybus L). J. Sci. Food Agric., 76: 107-110.

Von-Loesecke, H.W.(1955).Drying and Dehydration of Foods.Chaphrman and Hall, LTD., London, pp 330. 


\section{الملخص العربي}

\section{انتاج وتقييم بعض المنتجات الخاصة الخحضرة من القمة النامية(الجمار) لشجرة نخيل البلح الزغلول}

$$
\text { ماجدة سالم شرارة, السيد يُمّمج أبو طور, على أحمد عبد النبى }
$$

وعلى الرغم من انخفاض محتوى الجمار الطازج ودقيقه المجفف من كل مـن حـامض الاسـكوربيك والمركبـات الفينوليـة الا أنسه يمكـن أعتبـاره

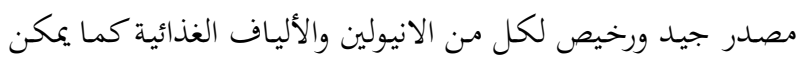
اعتباره مصدرا" جيدا" وطبيعيا كمـانع للأكسـدة. كمـا يمكن اعتبار

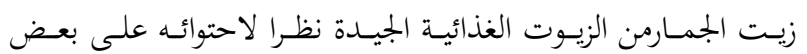

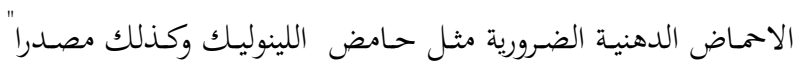

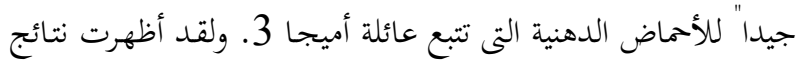
الاختبارات العضوية الحسية أن فترة صلاحية شرائح الجمار الطازجة

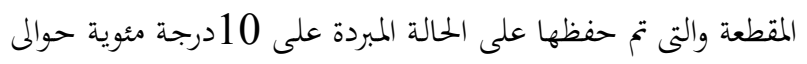

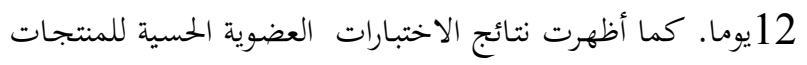

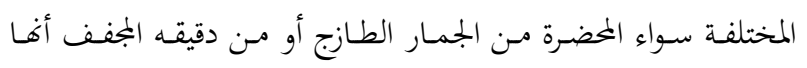
مقبولةحسيا وبدرجة جودة عالية.
تم دراسـة بعضض الحــواص الكيموطبيعيـة والتركيسب الكيمـاوى

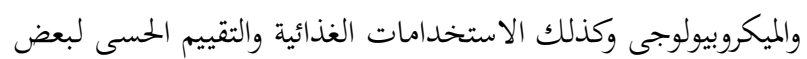

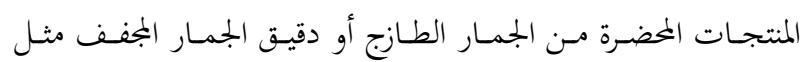

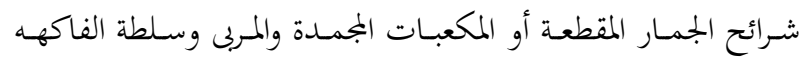
بالاضـافة الى بعض المنتجـات الأخــى المضـاف اليهـا دقيـق الجمـار المجفف مثل البسكويت والكوكيز والبليلة والبودنج. أشارت نتائج الدراسة الى أن محتوى المواد الصلبة الذائبة في الجمار

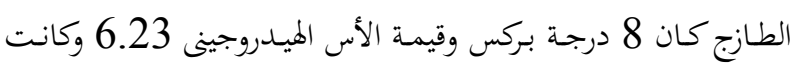

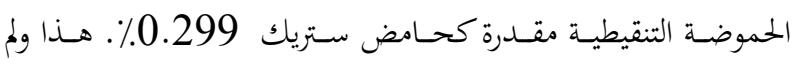
يحتوى كل من الجمار الطازج ودقيق الجمار المجفف على أية كميات

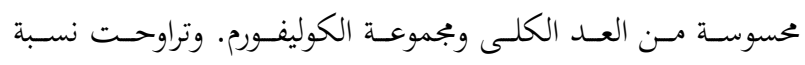

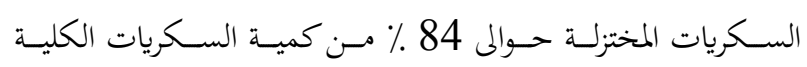

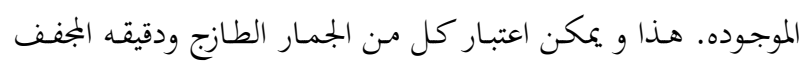

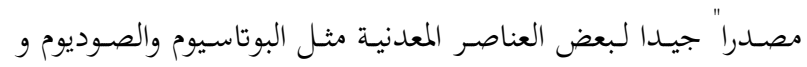

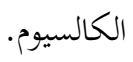

